Relations industrielles

Industrial Relations

\title{
Auteurs des ouvrages recensés
}

Volume 26, numéro 4, 1971

URI : https://id.erudit.org/iderudit/028291ar

DOI : https://doi.org/10.7202/028291ar

Aller au sommaire du numéro

Éditeur(s)

Département des relations industrielles de l'Université Laval

ISSN

0034-379X (imprimé)

1703-8138 (numérique)

Découvrir la revue

Citer ce document

(1971). Auteurs des ouvrages recensés. Relations industrielles / Industrial

Relations, 26(4), 1096-1097. https://doi.org/10.7202/028291ar

Tous droits réservés @ Département des relations industrielles de l'Université Laval, 1971
Ce document est protégé par la loi sur le droit d'auteur. L’utilisation des services d'Érudit (y compris la reproduction) est assujettie à sa politique d'utilisation que vous pouvez consulter en ligne.

https://apropos.erudit.org/fr/usagers/politique-dutilisation/ 


\section{Auteurs des ouvrages recensés}

$\mathrm{X} \times \mathrm{X}$, Le potentiel de développement des cadres, no 2, p. 514A.

ADELL, B.L., The Legal Statut of Collective Agreements in England, the United States and Canada, no 2, p. 510.

ARCHIBALD, Kathleen, Les deux sexes dans la fonction publique, no 1, p. 251.

B I T, La participation des travailleurs aux décisions dans les entreprises, no 1, p. 256.

BAIN, Georges Sayers, The Growth of White-Collar Unionism, no 2, p. 510A.

BASS, B.M., VAUGHAN, J.A., Training in Industry: The Management of Learning, no 3 , p. $782 \mathrm{~A}$.

BASSEY, Michael, Science and Society, The Meaning and Importance of Scientific Method, no 2, p. 518.

BELANGER, Laurent, Evolution du patronat et ses répercussions sur les attitudes et pratiques patronales dans la province de Québec, no 1, p. 248.

CHERNICK, Jack, Adaptation and Innovation in Wage Payment Systems in Canada, no 1, p. 241A.

CHEVALIER, M., CHORIVIT, J., Les Business Schools Américaines, no 1, p. 255A.

CHRISTIE, Innis, GORSKY, M., Unfair Labor Practices: An Explanatory Study of the Efficacy of the Law of Unfair Labour Practices in Canada, no 1, p. 245.

COMTE, Philippe, Valeurs économiques et valeurs juridiques dans les fusions d'entreprises, no 2, p. 517.

DOFNY, J., BERNARD, P., Le syndicalisme au Québec: structure et mouvements, no 1, p. 244.

FEJTO, François, Dictionnaire des partis communistes et des mouvements révolutionnaires, no 4, p. 1056A.

FLOOD, Maxwell, Wildcat Strike in Lake City, no 1, p. 249.

GERVAIS, Jacques, De la prévision économique à la gestion financière, no 2, p. 516.

HAMELIN, Jean et Alii., Répertoire des grèves dans la province de Québec au XIXe siècle, no 4, p. 1054.

HARBISON, F.H. et Alii., Quantitative Analysis of Modernization and Development, no 2, p. 514.

KAMIN, Alfred, Western European Labor and the American Corporation, no 2, p. $518 \mathrm{~A}$.

KORMAN, Abraham K., Industrial and Organizational Psychology, no 2, p. 513.

LAMURE, Dominique, GAP: Initiation pratique, no 4, p. $1056 \mathrm{~B}$.

LOUSER, Jan J., FULLAN, M., Industrial Conversion and Workers' Attitudes to Change in Different Industries, no 1, p. 246.

MAIER, N.R., L'entretien d'appréciation: six dialogues entre chef et subordonné, no 1 , p. 255B.

MALLES, Paul, Economic Consultative Bodies: Their Origins and Institutional Characteristics, no 4, p. 1055A. 
MALLES, Paul, Trends in Industrial Relations Systems of Continental Europe, no 2, p. 508.

MENETRIER, Dr Jacques, La médecine en mutation, no 1, p. 257A.

MORIN, Fernand, Le Code du travail: sa nature, sa portée, ses effets, no 4, p. 1056.

NOONE, Donald J., Teachers vs School Board, no 3, p. 783A.

O C D E, Flexibilité de l'âge de la retraite, no 3, p. 775.

O CDE, Retour des femmes sur le marché du travail après interruption d'emploi, no 3, p. 776.

OLMI, André, JULY, F., Lexique du calcul économique et de l'économétrie, no 2 , p. 512.

PENZ, Peter G., Structural Unemployment Theory and Measurement, no 1, p. 257.

PERIGOE, J.R., HERCUS, T., The Best of Canadian Personnel Journal, no 4, p. 1055.

REYNOLDS, Lloyd G., Labor Economics and Labor Relations, no 1, p. 254.

RIGG, Robinson P., L'audiovisuel au service de la formation, méthodes-matériels, no 2, p. 517A.

ROBERT, M.A., Psychologie du groupe, no 1, p. 255.

ROBERTS, Harold S., Labor-Management Relations in the Public Service, no 2, p. 511 .

SHOSTAK, Arthur B., Blue-Collarite, no 4, p. 1049.

SOLASSE, Bernard, Syndicalisme, consommation et société de consommation, no 1, p. 241.

STERN, Gerald Emmanuel, Gompers, no 3, p. 784.

TANNENBAUM, Arnold S., Social Psychology of the Work Organization, no 3, p. 782 .

TIFFANY, D.W. et Alii., The Unemployed: A Social-Psychological Portrait, no 3, p. 781.

VERLHAC, Colette, Les méthodes d'intégration dans l'entreprise à Grenoble, no 2 , p. 515.

WESTLEY, William and Margaret, The Emerging Worker, no 3, p. 776A.

WILLIAMS, C.G., Labor Economics, no 4, p. 1054A.

WOOD, W.D. et Alii, Canadian Graduate Theses: 1919-1967; An Annotated Bibliography Covering Economic Business and Industrial Relations, no 1, p. 253A.

WOOD, W.W., CAMPBELL, H.F., Cost-Benefit and the Economics of Investment in Human Resources: An Annotated Bibliography, no 3, p. 783.

YVON, P.J., SEMIN, C., Comment concevoir un système intégré de gestion, no 2 , p. 516A.

ZAIDI, A. Mahmood, A Study of the Effects of the $\$ 1.25$ Minimum Wage Under the Canada Labour (Standards), no 1, p. 251A. 